\title{
The Role of Satya Wacana Christian University in Preparing for ICT Community
}

\author{
Slameto \\ Magister of Educational Management \\ Universitas Kristen Satya Wacana Salatiga, Indonesia \\ slameto@staff.uksw.edu
}

\begin{abstract}
The objectives of this study were 1) to analyze the success level of the alumni of the Open/Distance Learning (O/DL), the Bachelor Education In-service Teachers Program (BEITP), Satya Wacana Christian University (SWCU), Salatiga in terms of their readiness to enter the ICT community, 2) to identify contributing factors in classroom lectures which become determinants for the success of the alumni in their readiness to enter ICT community, and 3) to determine the extent of the determinant effects which are to be found. The contributing factors which are assumed to affect the students' readiness to enter ICT community are the students' cognitive ability, the teacher's authority, the students' learning activeness, and the students' motivation in learning. This quantitative research is the causality ex-post facto research. The data source is one of the four classes of the BEITP SWCU students, which comprises 32 alumni of the 2015/2016 class. The data are screened by a self-rating scale (questionnaire) which includes valid and reliable 40 items, which are then reduced into 5 variables. The BEITP SWCU Salatiga program have graduated most of the alumni who have readiness to enter the ICT community at the medium and high levels. This achievement is influenced by the teacher's authority as well as students' meta-cognition as high as $40.80 \%$. Eventually, the only determinant for the achievement has been the students' cognition ability which contributes $37.20 \%$. This metacognition-based class management is worth developing in order to improve the quality of Higher Education Institutions which carry out the BEITP Program using the ICT-based classes.
\end{abstract}

Keywords-ICT community, teacher's authority, meta-cognition ability, learning activity, learning motivation

\section{INTRODUCTION}

Education is a place for community empowerment [1], future orientation, an preparing students to encounter global change challenges. Education should play its role in preparing students in the constellation of the global community. Despite its future orientation, education remains to stand on the present condition [2]. The global community constellation is characterized with the advance of science and technology, especially the information and communication (ICT). The ICT community or the information community is often used to describe a community which uses the information technology tool in a high intensity in the everyday life. The community uses the same or compatible technology for a variety of personal, social, educational, business activities or even to kill time. The technology has the ability to send, receive, and exchange digital data in a high velocity disregarding distances. The ICT or information community is also called digital community [3].

Some of the indicators for the ICT community are seen from their ability in using the ICT both in individual and team works to support critical thinking, creativity and innovation for the sake of education, working networks, and recreational purposes; their being always critical and reflective when receiving information in the sense that there is a business motif in technology; being understanding of the consequences in using ICT, having a competence in understanding the impacts of using ICT in terms of values and responsibilities, and other behaviors; and being responsible in using technology, having sensitivity in using the internet [4].

In line with the reconstructionist principle, community condition always requires basic changes [5]. Here, education---letting alone Higher Education---should be competent in yielding products needed by the changes to become an ICT community. In the unfavorable condition of the Indonesian education, the problem is whether education, especially higher education is still able to play its role in producing alumni who are ready to enter the ICT community; what factors are contributing? It is a very important matter for the educational quality management to be concerned about the effectiveness and productivity of the Higher Education.

The problem in this research is limited on the Higher Education, especially on the O/DL, which is carried out by BEITP SWCU, Salatiga. The problem statements are 1) How big is the alumni's success rate in entering the ICT community? 2) What determining factors are contributing to the success of the alumni in entering the ICT community? In the educational perspective as a system, the result (the alumni's success in entering the ICT community) is directly affected by the process (learning management). Here, the students and the teacher play a principal role which needs a close attention [6]. Student factor includes metacognition ability $\left(\mathrm{X}_{1}\right)$, learning activeness $\left(\mathrm{X}_{3}\right)$, and learning motivation $\left(\mathrm{X}_{4}\right)$. Teacher factor includes professional work morale, which is seen in their authority in the students' eyes $\left(\mathrm{X}_{2}\right)$.

One of the important factors in learning is the metacognition. Metacognition is principally learning ability, i.e., how learning has to be done including considerations of the following activities: 1) developing plans to active learning, 2) identifying strengths and weaknesses in 
learning activities, 3) preparing learning programs for concepts, skills, and new ideas, 4) identifying and using daily experiences as a learning source, 5) utilizing modern technology as a learning source, 6) leading and participating in a group discussion in problem solving, 7) learning and making use of successful people's experiences in a particular area, and 8) understanding supporting factors for learning success [7]. Eventually, however, one's success in learning depends on his or her metacognition.

Metacognition is a term introduced by Flavell in 1976, who creates a lot of arguments in his definition. The result is that metacognition is not always the same in various researches in the field of psychology, and cannot be applied in only one psychology area. However, the meaning of metacogniton as explained by researchers in psychology generally gives an emphasis on one's awareness in thinking about his or her own thinking process [8]. Metacognition is a form of cognition, the second order or higher in the process of thinking which involves active control on the cognitive process. This can be described as thinking about thinking or, one's cognition on cognition. Metacognition is a form of cognition, or a process of immunisation, which includes a higher level of thinking, involving control over a cognitive activity. Metacognition is an awareness of our own cognition, that is, how cognition of our work is and how to control it. Such ability is very important especially for efficiency of using cognition in solving a problem [9].

Metacognition is the knowledge and the regulation of cognitive activity of a person in the learning process [10]. Meanwhile, metacognition refers to one's understanding of the depth of knowledge, so a deeper understanding about it or its knowledge will reflect an effective use or a clear explanation of the knowledge concerned [11]. It means that cognition knowledge is one's awareness of what is really known, and cognitive regulation is how one regulates his or her cognitive activities in an effective way. Thus, cognitive knowledge contains declarative, procedural, and conditional knowledge, while cognitive regulation includes planning, predicting, monitoring, testing, revising, correcting, and evaluating activities.

Authority can be understood as an ability to influence and to control others. Authority may arise from two things, charisma and performance [12]. Charisma usually arises by itself as an innate being from birth. Performance has the meaning of something related to work. So, a good performance is one's attraction to others by way of a good performance. It puts an emphasis on one's non-physical appearance. It is usually realized on the firm, intelligent, well-mannered, onsistent, honest attitudes and always has a solution when faced with a problem. Charisma usually is related with things embedded on one's personality from physical posture, form of face, speaking style, eye contact, to the way one walks.

Authority means the right to give orders and power to make us obeyed and followed with an attitude and behavior that can create reverence and respect [13]. Teacher's authority, therefore, is a teacher's attitude or presentation which can create reverence and respect to him or her, which originates from self-superiority and mastery of his or her competence in such a way that create student's willingness to follow classes, guidance and directions from the teacher concerned [14]. Teacher's authority is seen in his or her disciplined attitude, empathy, neat and well-mannered dress, mastery of teaching materials, use of various methods of teaching which are inspiring and pleasing, and an objective way of assessing the students.

An active learning means learning which needs to make all the students and the teacher active both physical (including all senses) and mental, and even moral and spiritual aspects. For example, when the class is learning about the characteristics of water (in Science), there must be a simple experiment so that everybody becomes active, all senses are involved, thinks, and analyzes in a way that the students know why the surface of water is always flat even though its container is made slanting. It can also be related to the glory of God in creating water for the life of mankind and that it has to be protected [15]. Some of the activeness are visual, oral (presentation of ideas systematically and meaningfully), listening activities (in listening, students are doing it consciously not only for words spoken by others more importantly understanding the message thoroughly), writing, and emotional activeness [16]. With active learning, it is hoped that the classes will become more effective, students will be more critical ad creative, learning atmosphere and experiences will vary, emotional and social maturity will be enhanced, students' productivity will be higher, and are ready to face changes and to participate in the process of change.

Motivation is the drive arising from a person consciously or to carry out an action with a particular objective [17]. Motivation comes from the word "motif', meaning a moving power within one's subject to do a particular activity to achieve an aim. It is also meant as an internal condition (readiness). Thus, motivation can be understood as a moving power which has been active at particular times to achieve an objective deemed to be urgent. For students in the classroom, their primary activity is to learn. Their motivation should have been realized in the following behaviors: always to come to classes, to get involved actively, to make notes diligently, to do assignments given by the teacher at their own will and consciousness, to read or to borrow and/or to make use of leisure time for study. In addition, students who have high motivation possess a target to achieve, a reward they deserve to receive, a competition for achievement among classmates, since for them to study is very important for their future life.

The objectives of this research are 1) to measure the level of success experienced by the alumni of O/DL Program, BEITP SWCU, Salatiga in the form of their readiness to enter ICT community, 2) to identify contributing factors which become determinants for the 
success of the alumni to enter ICT community as well as the extent or range of the influences to be found. These new findings are very useful for educational quality management, in terms of its effectiveness and productivity of Higher Education.

\section{METHOD}

This study was conducted based on the assessment of the alumni who had attended BEITP. The population of the study was alumni of Open/ Distance Learning Primary Teacher Training Program SWCU Salatiga scattered in 5 regions namely in Kebumen, Grobogan, District Pati, Kudus and Batang regency. The samples were randomly selected, taken from one districts namely Batang regency of 48 people.

Based on the formulation of the problem posed, it appeared that this research was inferential quantitative research. The quantitative research revealed inferential relationship between two or more variables that could explained the symptoms, which examined the effect of variables students' meta-cognition ability $\left(\mathrm{X}_{1}\right)$, teacher's authority $\left(\mathrm{X}_{2}\right)$, students' learning activeness $\left(\mathrm{X}_{3}\right)$, and students' learning motivation $\left(\mathrm{X}_{4}\right)$ towards their readiness to enter ICT community (Y); and then found the determinant variable of four independent variables in question. The time of this study was the 2nd half of 2014/2015.

Statistical Hypothesis - In ordinal order, the variable of readiness to enter ICT community of alumni, there was one dominant level among four categories: low, medium, high and very high. Among the 4 independent variables, there were positively significant determinant on the readiness to enter ICT community of alumni. In other words, the regression coefficient predictor determinant $\left(b_{1}\right)$ was significantly positive. Statistical hypothesis proposed were:

$\mathrm{H}_{0}: \mathrm{b}_{1}=0$ (there is no determinant influence on readiness to enter ICT community of alumni of BEITP for teachers through open/distance learning)

$\mathrm{H}_{1}: \mathrm{b}_{1} \neq 0$ (there is a determinant influence on readiness to enter ICT community of alumni of BEITP for teachers through open/distance learning)

The effects on individual or multiple was discovered by looking at the value of $b$ in the determinant variable. Furthermore, the significance of value $b$ will be tested by $t-$ test. $\mathrm{T}$ significance was seen in its value. If $\mathrm{b}$ was positive, and $t$ was significant at an error rate of less than 0.05 , the hypothesis $\mathrm{H}_{1}$ would be accepted.

Instruments and Data Analysis Techniques - The data of this study was quantitative data in the form of numbers; Ordinal data was data that was expressed in forms of categories and ranked. Ordinal scale used was the ranking scale (Likert Scale) that consists of statements and answers with low, medium, high and very high corresponding to measurement purposes. Data were collected through a selfrating scale consisting of 40 items that had been proven its validity and reliability; Score validity 0.199 to 0,827 , with a reliability index Cronbach's alpha $=0.93$.

Data of values of variables were analyzed by using frequency distribution and linear regression (double) with Stepwise Model. Furthermore, the researcher creates the model of relationship (causal models). The patterns of the independent variables influence (determinant) on the dependent variable was tested by $\mathrm{F}$ test at the 0.05 level. This calculation was carried out with SPSS version 20 .

In the testing concept model, the determinant coefficient from the independent variable to the dependent variable was calculated. The calculation result of the determination coefficient from four independent variables in this study on the dependent variable was adjusted by $\mathrm{R}^{2}$ coefficient. If the significance $\mathrm{r}$ was less than or equal to 0.05 , this model was declared significant, as $\mathrm{X}_{1-4}$ (selected) influenced $\mathrm{Y}$, as much as adjusted $\mathrm{R}^{2}$ coefficient.

\section{DATA ANALYSIS}

Descriptive analysis - After the data screening by selfrating scale, consisting of 40 items, which were then reduced to 5 , they were analyzed descriptively using the SPSS program for Windows version 20. The result is as follows.

\section{TABLE 1. STATISTICS}

\begin{tabular}{|l|l|l|l|l|l|}
\hline $\begin{array}{c}\text { Statistical } \\
\text { Index }\end{array}$ & Var $\mathbf{X}_{\mathbf{1}}$ & Var $\mathbf{X}_{\mathbf{2}}$ & Var $\mathbf{X}_{\mathbf{3}}$ & $\operatorname{Var} \mathbf{X}_{\mathbf{4}}$ & Var $\mathbf{Y}$ \\
\hline Mean & 2.6364 & 2.2273 & 2.7273 & 2.7273 & 2.6364 \\
\hline Median & 3.0000 & 2.0000 & 3.0000 & 3.0000 & 3.0000 \\
\hline Sd. & .58109 & .42893 & .55048 & .55048 & .65795 \\
\hline Variance & .338 & .184 & .303 & .303 & .433 \\
\hline Minimum & 2.00 & 2.00 & 2.00 & 2.00 & 2.00 \\
\hline Maximum & 4.00 & 3.00 & 4.00 & 4.00 & 4.00 \\
\hline
\end{tabular}

Based on the result of the descriptive analysis as shown in Table 1 above, most respondents consider their metacognition $\left(\mathrm{X}_{1}\right)$ at high level, the teacher's authority $\left(\mathrm{X}_{2}\right)$ at medium level, their learning activeness $\left(\mathrm{X}_{3}\right)$ at high level, and their learning motivation $\left(\mathrm{X}_{4}\right)$ at high level, and their readiness to enter the ICT community (Y) at mid-high level.

Hypothesis testing - The next analysis is to know whether the five free variables $(\mathrm{X})$ give effects to the students' readiness to enter the ICT community (Y). If it is true, how far is their effect? The result of the regression analysis is shown in Table 2 below.

TABLE 2. MODEL SUMMARY

\begin{tabular}{|c|c|c|c|c|}
\hline Model & $\mathbf{R}$ & R Square & $\begin{array}{c}\text { Adjusted } \\
\text { R Square }\end{array}$ & $\begin{array}{c}\text { Std. Error of the } \\
\text { Estimate }\end{array}$ \\
\hline 1 & $.722^{\mathrm{a}}$ & .521 & .408 & .50611 \\
\hline
\end{tabular}

a. Predictors: (Constant), $\mathrm{X}_{4}, \mathrm{X}_{1}, \mathrm{X}_{2}, \mathrm{X}_{3}$

Based on the result of regression test as presented in the above table, it is clear that the $\mathrm{R}$ gained is 0,722 and $\mathrm{R}$ Square Adjusted $=0,408$ or $40,80 \%$. To make sure if the 
size of $\mathrm{R}$ is signifikan, the following Table 3 Anova shows it.

TABLE 3. ANOVA

\begin{tabular}{|l|c|c|c|c|c|}
\hline \multicolumn{1}{|c|}{ Model } & $\begin{array}{l}\text { Sum of } \\
\text { Squares }\end{array}$ & df & $\begin{array}{l}\text { Mean } \\
\text { Square }\end{array}$ & F & Sig. \\
\hline Regression & 4.736 & 4 & 1.184 & $\mathbf{4 . 6 2 3}$ & $\mathbf{. 0 1 0}^{\text {a }}$ \\
\hline Residual & 4.355 & 17 & .256 & & \\
\hline Total & 9.091 & 21 & & & \\
\hline
\end{tabular}

a. Predictors: (Constant), $\mathrm{X}_{4}, \mathrm{X}_{1}, \mathrm{X}_{2}, \mathrm{X}_{3}$

b. Dependent Variable: Y

Based on Table 3 Anova above, the $F=4,623$ at the significant level 0,010 . This level of significance 0,010 is smaller than 0.05 . Therefore, the students' meta-cognition ability $\left(\mathrm{X}_{1}\right)$, the teacher's authority $\left(\mathrm{X}_{2}\right)$, the learning activeness $\left(\mathrm{X}_{3}\right)$, and the learning motivation $\left(\mathrm{X}_{4}\right)$ altogether give positive and significant effects to their readiness to enter the ICT community at $40.80 \%$. Next, the role of each predictor variable can be seen in the following Table 4 .

TABLE 4. COEFFICIENTS ${ }^{A}$

\begin{tabular}{|c|c|c|c|c|c|c|}
\hline & \multirow{2}{*}{ Model } & \multicolumn{2}{|c|}{$\begin{array}{c}\text { Unstandardized } \\
\text { Coefficients }\end{array}$} & \multirow{2}{*}{$\begin{array}{c}\begin{array}{c}\text { Standardized } \\
\text { Coefficients }\end{array} \\
\text { Beta } \\
\end{array}$} & \multirow{2}{*}{$\mathbf{t}$} & \multirow{2}{*}{ Sig. } \\
\hline & & $\boldsymbol{B}$ & $\begin{array}{l}\text { Std. } \\
\text { Error }\end{array}$ & & & \\
\hline \multirow[t]{5}{*}{1} & (Constant) & 0.084 & 1.168 & & 0.072 & 0.944 \\
\hline & $\mathbf{X}_{1}$ & .739 & .197 & .653 & 3.744 & .002 \\
\hline & $\mathbf{X}_{2}$ & .478 & .262 & .311 & 1.621 & .046 \\
\hline & $\mathbf{X}_{3}$ & -.047 & .211 & -.039 & -.222 & .827 \\
\hline & $\mathbf{X}_{4}$ & -.122 & .204 & -.102 & -.597 & .559 \\
\hline
\end{tabular}

a. Dependent Variable: Y

Based on Table 4, the coeffisient of students' readiness to enter the ICT community gets only 2 predictors, namely: the students' meta-cognition ability $\left(\mathrm{X}_{1}\right)$ and the teacher's authority $\left(\mathrm{X}_{2}\right)$ have significance level less than 0.05 , while the learning activeness variable $\left(\mathrm{X}_{3}\right)$ and the learning motivation $\left(\mathrm{X}_{4}\right)$ do not affect significantly on their readiness to enter the ICT community. In addition, to know determinants for the students' readiness to enter the ICT community, a regression analysis using the stepwise model gives the following result as shown in Tables 5 and 6 below.

TABEL 5: MODEL SUMMARY

\begin{tabular}{|c|c|c|c|c|}
\hline Model & $\mathbf{R}$ & $\begin{array}{c}\mathbf{R} \\
\text { Square }\end{array}$ & $\begin{array}{c}\text { Adjusted R } \\
\text { Square }\end{array}$ & $\begin{array}{c}\text { Std. Error of the } \\
\text { Estimate }\end{array}$ \\
\hline $\mathbf{1}$ & $\mathbf{. 6 3 4}^{\mathrm{a}}$ & $\mathbf{. 4 0 2}$ & $\mathbf{3 7 2}$ & $\mathbf{. 5 2 1 3 4}$ \\
\hline
\end{tabular}

a. Predictors: (Constant), Var $\mathrm{X}_{1}$

Based on the result of the regression test as shown on the table above, the $\mathrm{R}=0.634$ and the $\mathrm{R}$ Square Adjusted = 0.372 or $37.2 \%$. To make sure whether the value of $\mathrm{R}$ is significant, the following Anova table shows it.

TABLE 6. ANOVA ${ }^{\mathrm{B}}$

\begin{tabular}{|l|l|c|c|c|c|c|}
\hline \multicolumn{2}{|c|}{ Model } & Sum of Squares & & Mean Square & F & Sig. \\
\hline \multirow{2}{*}{ Regression } & $\mathbf{3 . 6 5 5}$ & 1 & $\mathbf{3 . 6 5 5}$ & $\mathbf{1 3 . 4 4 8}$ & $\mathbf{. 0 0 2}^{\mathbf{a}}$ \\
\cline { 2 - 7 } & $\mathbf{5 . 4 3 6}$ & $\mathbf{2 0}$ & .272 & & \\
\hline
\end{tabular}

TABLE 6. ANOVA ${ }^{\mathrm{B}}$

\begin{tabular}{|c|c|c|c|c|c|}
\hline Model & Sum of Squares & & Mean Square & $\mathbf{F}$ & Sig. \\
\hline Regression & 3.655 & 1 & 3.655 & 13.448 & $.002^{\mathrm{a}}$ \\
\hline Residual & 5.436 & 20 & .272 & & \\
\hline Total & 9.091 & 21 & & & \\
\hline
\end{tabular}

a. Predictors: (Constant), Var $\mathrm{X}_{1}$

b. Dependent Variable: Var Y

The above Anova table shows that the $\mathrm{F}=13.448$ at the significance level 0.002 , which is smaller than 0.05 . It can be concluded, therefore, that the meta-cognition ability becomes the determinant or predictor positively and significantly for the learning achievement in the form of their readiness to enter the ICT community at $37.2 \%$.

\section{DISCUSSIONS}

This research has measured the readiness of the students of the O/DL Program, BEITP SWCU, Salatiga to enter the ICT community. It is clear that the O/DL Program, BEITP SWCU, Salatiga has produced alumni, most of whom possess readiness to enter the ICT community at the medium and the high levels. This achievement has been affected by the teacher's authority and the students' metacognition ability. Eventually, the only determinant of the learning achievement is the students' cognition ability.

In relation with teacher's authority, the result above is congruent with the findings by Astuti, Rahayu Puji [18], who concluded that teacher's authority in teaching at the high category is $18 \%$, that at the medium category is $60 \%$, and that at the low category is $22 \%$. This research concluded that teacher's authority which affected students' readiness to enter the ICT community is $3.60 \%$.

In relation with the O/DL, BEITP SWCU students' learning motivation $\left(\mathrm{X}_{4}\right)$, the present research found it at the high level. It is somewhat different from the research finding in references [18], who concluded that students' motivation in learning varies, namely, that at the high category $8 \%$, at the medium category $72 \%$, and that at the low category $20 \%$. Thus, the learning motivation of most students $(72 \%)$ is at the medium category. Further, this research concludes that learning motivation $\left(\mathrm{X}_{4}\right)$ does not affect in a significant way on their readiness to enter the ICT community. Unlike a research in references [19], who concluded that learning motivation affected positively on their learning achievement on entrepreneurship of students of Universitas Muhammadiyah Surakarta, class of 2008, saying that its effective contribution is $16,9 \%$. This research resembles that of in references [20], who concluded that learning motivation affected the least $(2 \%)$ on the learning result.

Learning activeness is students' activity in the learning process which serves as a measure of the quality of the learning itself. Learning activeness may affect students' learning achievement. This research found that students' learning activeness $\left(\mathrm{X}_{3}\right)$ tdoes not affect their readiness to 
enter the ICT community significantly. It is in contrast with the research finding in references [16], who argued that there is a relationship between learning activeness and learning achievement of the students taking Plant Ecology class at Biology Education Study Program, FKIP, UMS, in the odd semester of the academic year 2014/2015.

Research on meta-cognition has become important, the research shows that meta-cognition awareness has a direct positive relationship with academic achievement [21], while orientation of performance objective has a direct but negative relationship with academic achievement. The result of this research also shows that self-efficacy and learning objective orientation is indirectly related with academic achievement through meta-cognition awareness. However, research in Indonesia shows an opposite finding on the effect of meta-cognition on learning achievement. Research in references [22] found that meta-cognition affected positively and significantly on learning achievement both directly and indirectly. This research agrees with that in references [21]. On the other hand, 2 years later in references [23] found "there is no effect of meta-cognition on learning achievement in the aspects of knowledge, attitude, and students' skills."

The finding in this research is parallel with the conclusion of a research, who argued that meta-cognition affects learning achievement positively and significantly at $1 \%$. Similarly, in references [22] found that the directly effective contribution of meta-cognition variable on learning achievement in Mathematics is $41 \%$ and that indirectly (through self-regulation) is 58\%. This research rejects the research finding in references [23], saying that the statement "there is no effect of meta-cognition ability on learning achievement in the aspects of knowledge, attitude, and students' skills" is not supported by data.

The new research findings are very important for educational quality management in pursue of effectiveness and productivity of Higher Education. The important characteristics of meta-cognitive approach is, rather than imposing on the students with the objective or particular result, it is better to encourage students to identify articulation and achievement of relevant personal objective, including that related to skills, attitude, belief, values and understanding, integration and school leadership [24]. To further understand, in references [25], who conducted a research on factors which affect levels of meta-cognition in a problem solving, found that there is a relative similarity in respective scores, that is, the internal factor (students' memory in the subject to be mastered and their learning strategy to be employed) and the external factor (availability of learning facility at home, opportunity to express ideas or thoughts from parents during children/ students' study hours, parents' attention, and students' participation in campus organizations).

The management of metacognition-based instruction, although it is not yet developed, makes it possible for teachers to make a reflection on their process of instruction, both at individual level and group level (for example, in the conference and group product on the on-line electronic selfassessment). Stimulating teachers and students to think about teaching-learning process (ICT-based instruction) may make some aspects of teacher's pedagogy more accurate, effective and efficient [26]; [27]. These new findings will be useful for the management of educational quality for the sake of effectiveness and productivity of Higher Education as an executor of ICT-based instructions in O/DL Program.

\section{CONCLUSION}

This research has measured the readiness of students of the $O / D L$ Program, BEITP SWCU, Salatiga in entering the ICT community. It was found that the $O / D L$ Program, BEITP SWCU, Salatiga has produced most of their alumni with readiness to enter the ICT community at the medium and high rates. The achievement is made possible by the effect of teacher's authority and students' meta-cognition ability at $40.80 \%$. At the other end, the only determinant of learning achievement is the students' cognitive ability, which contributes as much as $37.20 \%$, while the students' learning activeness and learning motivation variables do not affect significantly upon their readiness to enter the ICT community.

The management of meta-cognitive-based instructions is interesting to develop since it enables teachers to make a reflection on the process of their instructions both individually and in groups. Encouraging teachers and students to think about teaching-learning process (ICTbased instructions) may make the teacher's pedagogic aspect more accurate, effective, and efficient, which in turn will be very useful for the educational quality management, concerning the effectiveness and productivity of the Higher Education as an executor of the ICT-based $O / D L$ program instructions.

\section{REFERENCES}

[1] Wiggins, N., Johnson, D., Avila, M., Farquhar, S. A., Michael, Y. L., Rios, T., \& Lopez A. Using popular education for community empowerment: perspectives of Community Health Workers in the Poder es Salud/Power for Health program. Crit Public Health. 2009;19(1).

[2] Jalal, Fasli dan Supriadi D. Reformasi Pendidikan Dalam Konteks Otonomi Daerah. Yogyakarta: Adicita Karya Nusa; 2001.

[3] Wikipedia Bahasa Indonesia. Masyarakat informasi [Internet]. 2016. Available from: https://id.wikipedia. org/wiki/Masyarakat_informasi

[4] Susanti T. Indikator tanggap ICT [Internet]. 2012. Available from: http://susanti-vip.blogspot.co.id/ 2012/05/indikator-tanggap-ict.html

[5] Sanaky HA. Paradigma Baru Pendidikan Islam: Sebuah Upaya Menuju Pendidikan yang Memberdayakan. El Tarbawi. 2016;IV:515 .

[6] Miarso Y. Peningkatan kualifikasi guru dalam perspektif teknologi pendidikan. J Pendidik Penabur. 2008;10:66-76. 
[7] Taccasu Project. Metacognition [Internet]. 2008 [cited 2013 May 19]. Available from: http://www.careers. hku.hk/taccasu/ref/metacogn.html

[8] Gredler ME. Learning and Instruction: Teori dan Aplikasi. Jakarta: Kencana; 2011.

[9] Wellman H. The origins of metacognition. In D. L. Forrest-Pressley, G. E. MacKinnon, and T. G. Waller. Metacognition, Cogn Hum Perform. 1985;1 (Theoretical Perspectives):1-31.

[10] Flavell JH. Metacognition and cognitive monitoring: A new area of cognitive-developmental inquiry. Am Psychol. 1979;34(10):906.

[11] Moore M. Editorial: First thoughts on metaskills. Am J Distance Educ. 2002;16(1):1-4.

[12] Munir A. Super Teacher Sosok Guru yang dihormati, disegani, dan dicintai. Yogyakarta: Pedagogia; 2010.

[13] Sobri. Strategi Menuju Guru Profesional Persfektif Islam [Internet]. 2016. Available from: https://jambi.kemenag.go.id/files/ jambi/file/ file/artikel2016/atfu1468915873.pdf

[14] Khakim N. Seleksi Sertifikasi Guru Tahun 2012 Diperketat [Internet]. 2011. Available from: http://hakimnina.blogspot.co.id/ 2011_11_01_archive.html

[15] Slameto. Manajemen Berbasis Sekolah. Salatiga: Satya Wacana University Press; 2015.

[16] Sumiati S. Hubungan Keaktifan Belajar Terhadap Prestasi Belajar Mahasiswa Yang Mengikuti Mata Kuliah Ekologi Tumbuhan Pada Program Studi Pendidikan Biologi Fkip Universitas Muhammadiyah Surakarta Semester Gasal Tahun Akademik 2014/2015. Universitas Muhammadiyah Surakarta; 2015.

[17] Depdikbud. Kurikulum Pendidikan Dasar GBPP. Jakarta: Depdikbud; 1994.

[18] Astuti RP. Hubungan Kewibawaan Dosen Dengan Motivasi Belajar Mahasiswa Program Studi Pendidikan Agama Islam Angkatan 20092010 STAIN Salatiga Tahun 2013. STAIN Salatiga; 2014.

[19] Irianti R. Prestasi Belajar Kewirausahaan ditinjau dari Persepsi peluang kerja dan Motivasi Belajar pada Mahasiswa FKIP Pendidikan Akuntasi Universitas Muhammadiyah Surakarta Angkatan 2008. Universitas Muhammadiyah Surakarta; 2012.

[20] Nugraheni F. Hubungan Motivasi Belajar Terhadap Hasil Belajar Mahasiswa (Studi Kasus Pada Mahasiswa Fakultas Ekonomi UMK). Sos Budaya [Internet]. 2009; Available from: eprints.umk.ac.id

[21] Young, A., \& Fry JD. Metacognitive awareness and academic achievement in college students. J Scholarsh Teach Learn. 2008;8(2):1-10.

[22] Ilhamsyah I. Pengaruh Efikasi Diri, Metakognisi dan Regulasi Diri Terhadap Prestasi Belajar Matematika Siswa Kelas X Sma Negeri Di Kabupaten Wajo. JKIP. 2014;1(1):10-20.

[23] Nadi CY. Pengaruh Metode Problem Solving Secara Algoritmik dan Heuristik Terhadap Prestasi Belajar Ditinjau Dari Kemampuan Metakognisi Siswa Pada Materi Kelarutan dan Hasil Kali Kelarutan Kelas XI MIA di SMA N 5 Surakarta. 2016.

[24] Phelps, R., Graham, A., \& Kerr B. Teachers and ICT: Exploring a metacognitive approach to professional development. Australas $\mathbf{J}$ Educ Technol. 2004;21(1):49.

[25] Alkadrie, RP. dan Mirza A. Faktor-Faktor yang Mempengaruhi Level Metakognisi Dalam Pemecahan Masalah Pertidaksamaan Kuadrat di SMA. J Pendidik dan Pembelajaran [Internet]. 2015; Available from: untan.ac.id

[26] Harrison C. 11 ICT and Classroom Pedagogies. Learn To Teach Using Ict Ed. 2012;154.

[27] Slameto. The Determinants of the ICT- Based O/DL Program to
Encourage and Support the Country's Economy. In: Proceeding of International Conference on Teacher Training and Education (ICTTE) FKIP UNS 2015. Surakarta: Universitas Sebelas Maret; 2016. 